\title{
THE INFLUENCE OF ORGANIZATIONAL CLIMATE AND WORK MOTIVATION ON THE PERFORMANCE OF SAMSAT MEMBERS OF MADIUN
}

\author{
Jimmy Manurung, Indonesian Police Science College \\ jimmymanurung71rs@gmail.com
}

Citation: Manurung Jimmy, The Influence of Organizational Climate And Work Motivation On The Performance Of Samsat Members Of Madiun, Management Technology and Security International Journal, pages: 11-29

Received on 02 June 2020, Accepted on 09 July 2020, Published on 1 August 2020

\begin{abstract}
The aims of the study is to investigate factors influencing performance, and specifically to analyse the influence of organizational climate on Madiun Samsat members' performance and the influence of motivation on Madiun Samsat members' performance and the influence of organizational climate and work motivation simultaneously on Madiun Samsat members' performance. The study is conducted on 57 members of Madiun Samsat. Data collection is done through surveys and quantitative analysis techniques that are explained through hypothesis testing using multiple linear regression analysis using SPSS 19. The results of the study prove that all research instruments and data met the principles of validity, reliability and normality so that hypothesis testing can be done to predict the relationship of independent variables with the dependent variables partially or simultaneously, with the following results: 1) Organizational climate has a partial effect on the members' performance with the most dominant indicator at work is the indicator of responsibility; 2) Work motivation has a partial effect on the members' performance with a dominant influence derived from indicators of the need for selfactualization; and 3) Organizational climate and work motivation simultaneously influence members' performance, with the dominant influence coming from indicators of self-actualization needs. The results of this study make a practical contribution in improving the performance of Madiun Samsat members by continuing to motivate and maintain a conducive working climate by paying attention to the responsiveness of each member and always providing supports to the members to always work as well as possible.
\end{abstract}

Keywords: organizational climate, work motivation, member performance, Samsat

\footnotetext{
${ }^{1}$ Samsat is joint office between local police with local government
} 


\section{INTRODUCTION}

\subsection{Background}

In management, human resources play a very important role in achieving organizational goals. Forward progress of an organization depends on its human resources. Thus every organization must always improve the quality of the performance of its human resources to realize the achievement of the goals set. Every organization strives to achieve its organizational goals. One effort that can be done to achieve these goals is to create an organizational climate that is able to bring its members to improve performance in the ontext of achieving organizational goals (Herman, Jailani and Ibrahim, 2014). This organizational climate perception can be seen from various aspects, such as the way the organization treats its members, which in turn affects the members' interpretation of the organizational motives that underlie such treatment. This condition can further influence the feelings of members who increasingly wish to feel a condition that provides support for the organization in a variety of situations. Furthermore, the existence of good belief from an organizational climate that supports this organization correlates with external motivations within these members, which in turn can have an impact on a member's internal motivation.From this motivation, someone will work as much as possible, and in the end such motivation will have an impact on the performance of members.

Based on the explanation above, it is necessary to ask how much influence the organizational climate and work motivation have on the performance of Madiun Samsat members, which are the objects of this study. It is a fact that traffic department of Madiun Police Resort is an element of the Republic of Indonesia National Police institution which is built actually to provide services to the public. Based on Law Number 2/2002 concerning Polri, which has a central position to maintain security and public order, enforce the law, and provide protection and services to the community. Based on this law, the traffic department is required to provide good services to the community at any time.

The traffic department is an executing element whose job is to carry out police duties which include guarding, regulating, escorting, patrolling, community education and traffic engineering. In addition, the traffic department also conducts routine activities, such as registration and identification of motor vehicle drivers, traffic accident investigations and law enforcement in the field of traffic. Such duties are really important in creating and maintaining a safe, orderly and smooth atmosphere during traffic. While other activities at the executive level can be exemplified by following up on a number of basic tasks, especially those related to services in the areas of a driving license, vehicle number certificate, motor vehicle ownership book and investigation of traffic accidents.

But looking at the phenomena that exist, the implementation of tasks in Madiun Samsat still encounter public dissatisfaction with the services provided. This is known based on data obtained through the division of professionals and internal security unit regarding community complaints against the implementation of tasks carried out by the personnel of the traffic department. Some of these complaints are in the law enforcement service unit with action against traffic violators in the field, as well as in the investigation of road accident cases. Some contributing factors include a series of administrative procedures that are not short and not timely done by officers, then among traffic officers, inappropriate attitudes that do not reflect the figure as patron, protector and public servant when taking action on the highway are still found. Based on the results of the observations, it is known that some things that show 
that the performance of Madiun Samsat members is not optimal due to the presence of several members who do not carry out their duties and obligations, and lack of discipline in working both at office hours and in the process of carrying out tasks, where matters this can be observed in Table 1 below:

Table 1 Attendance list of Madiun Samsat Members (2012-2016)

\begin{tabular}{|c|c|c|c|c|c|}
\hline Year & \multirow{2}{*}{$\begin{array}{c}\text { Amount of } \\
\text { Personnel }\end{array}$} & \multirow{2}{*}{$\begin{array}{c}\text { Effective } \\
\text { Day }\end{array}$} & \multicolumn{3}{|c|}{ Presence } \\
\cline { 3 - 6 } & & & Sick* & not present & Total \\
\hline 2012 & 54 & 292 & 2 & 5 & 7 \\
\hline 2013 & 55 & 289 & 3 & 4 & 7 \\
\hline 2014 & 55 & 293 & 4 & 7 & 11 \\
\hline 2015 & 56 & 289 & 3 & 5 & 8 \\
\hline 2016 & 57 & 291 & 4 & 8 & 12 \\
\hline
\end{tabular}

*sick without a doctor's statement/ Source: Madiun Resort Police Traffic Unit, 2017

Such conditions, if left unchecked and not immediately corrected, can lead to a negative assessment of the community on the performance of the traffic department. This is not in line with the vision and mission of Polri in creating public order and security. More specifically, the traffic department is doing its best effort to create security, safety, order and smooth traffic flow. Therefore, the traffic department, especially its leaders must be able to create a conducive organizational climate, so as to condition a work environment that is able to make its members feel comfortable and have high morale and be able to convince the members that the organization assesses their contribution to the performance of the traffic unit of Madiun Police Resort, so that he or she will do his or her best in providing services to the community.

\subsection{Research Problem}

From the explanation above, it can be formulated that the problem of this research is how organizational climate and motivation influence the performance of Madiun Samsat members? From the formulation of this problem further detailed the main problems of this study are:

1) Is there a positive and significant simultaneous influence between organizational climate and motivation on the performance of Madiun Samsat members?

2) Does the organizational climate have a positive and significant effect on the performance of Madiun Samsat members?

3) Does motivation have a positive and significant effect on the performance of Madiun Samsat members?

\subsection{Research Objectives}

The purpose of this study is to answer the research problems, namely:

1) Analysing the simultaneous effect between organizational climate and motivation on the performance of Madiun Samsat members.

2) Analysing the influence of organizational climate on the performance of Madiun Samsat members.

3) Analysing the effect of motivation on the performance of Madiun Samsat members.

\section{LITERATUR REVIEW}

\subsection{Performance Theory}

Robbins (2008) defines performance as a result achieved by members in their work according to certain criteria that apply to a job. Meanwhile, Mangkunegara (2013:67) explains that performance is the result of 
work both in quality and quantity achieved by a member in carrying out tasks in accordance with the responsibilities given to him. Based on the opinions above, it can be concluded that performance is the result of work both in terms of quality and quantity achieved by members, in carrying out their duties in accordance with the responsibilities given by their organizations, and the results of their work are adjusted to the work expected by the organizations, through the criteria or performance standards of members that apply in the organization.

Furthermore, Robbin (2008:78) states that the success or failure of the performance achieved by the organization is influenced by the level of performance of members individually or in groups. It can be assumed that the better the performance of members, the better the performance of the organization. Thus, the organization needs to set members' police performance goals as follows:

a) The performance goal is to improve members' performance results, both in quality and quantity.

b) Provide new knowledge that will help members in solving complex problems, with a limited and regular set of activities, through tasks according to the responsibilities given by the organization.

c) Improve members'

personal relationships in work activities in the organization.

Members' performance is influenced by various factors, including:

a) Individual factors, namely abilities and skills (mental and physical), background (experience, family, etc.), and demographics (age, origin, etc.).

b) Organizational factors, namely resources, leadership, rewards (compensation), organizational structure, and job description.

c) Psychological factors, namely perceptions, attitudes, personality, learning patterns, and motivation.
(Mangkunegara, 2014: 88)”

In an organization, performance appraisal is an important mechanism for management to be used in explaining goals, performance standards, and motivating individual performance on an ongoing basis. In order to find out the good or bad performance of a member, it is necessary to do a performance appraisal, which is basically a key performance appraisal to develop an organization effectively and efficiently. Performance appraisal is the process by which the organization oversees the work of individual members. (Robbin, 2008:79).

The indicators of members' performance, according to (Mangkunegara, 2014: 88), are as follows:

a) Quality - the degree to which the results of activities carried out are near perfect, in the sense of adjusting some ideal ways of performing activities or meeting the expected goals of an activity.

b) Quantity - the number generated in terms of the number of units, the number of activity cycles completed.

c) Punctuality - the level of an activity is completed at the desired initial time, viewed from the point of view of coordinating with the outputs and maximizing the time available for other activities.

d) Effectiveness - the level of using of the organization's human resources is maximized with the intention of increasing profits or reducing the loss of each unit in the use of resources.

e) Independence - the degree to which a member can carry out his work function without asking for guidance from the supervisor or requesting the intervention of the supervisor to avoid adverse results.

Based on the explanation above, it can be concluded that performance is the result of work both in quality and quantity achieved by a member in carrying out 
tasks in accordance with the responsibilities given to him, as indicated through quality, quantity, timeliness, effectiveness and independence.

\subsection{Organizational Climate Theory}

Organizational climate is a physical element, where climate can be as an attribution of the organization or as an attribution of the individual's own perception. According to Simamora (2004:81), organizational climate is an internal environment or organizational psychology. Organizational climate influences human resources practices and policies accepted by members of the organization. Please note that each organization will have a different organizational climate. The diversity of jobs designed within the organization, or the nature of individuals that exist will illustrate these differences.

Lussier (2005: 486) states that organizational climate is the employee's perception of the quality of the organization's internal environment which is relatively felt by the members of the organization which will then affect their subsequent behaviour. According to Wirawan (2007:121), organizational climate is a quality of the internal environment that is relatively ongoing, experienced by the members of the organization, influencing the behaviour of each member.

In order to measure organizational climate, there are six dimensions needed (Wirawan, 2007:71), namely:

a) Structure - reflecting the organizational well-being and has clear roles and responsibilities in the organization's environment. A structure is high if the members of the organization feel their work is well defined. A structure is low if they feel there is no clarity about who is doing the tasks and has the authority to make decisions.

b) Standard-measuring the feeling of pressure to improve performance and the degree of pride possessed by the members of the organization in doing a good job. A high standard means that the members of the organization are always trying to find ways to improve their performance. A low standard reflects lower expectations for performance. The perception of high responsibility shows that members of the organization feel encouraged to solve their own problems. Low responsibility indicates that risk taking and trials of new approaches are not expected.

c) Responsibility-reflecting the employees' feelings that they are moving away from "their own boss" and does not require their decisions to be legitimized by other members of the organization. The perception of high responsibility shows that members of the organization feel encouraged to solve their own problems. Low responsibility indicates that risk taking and trials of new approaches are not expected.

d) Recognition or appreciationindicating that the members of the organization feel valued if they can complete the task well. High award is a measure of appreciation faced with criticism and penalties for completion of work. Climate organizations that value performance are characterized by a balance between reward and criticism. Low reward means that the completion of a job well is rewarded inconsistently.

e) Support-positive support from the leadership and other employees will create a conducive work situation. In addition, support also raises the team spirit of the workers so that they can trust and help each other, and there is a good relationship between workers in the work environment.

f) Commitment - reflecting the members' feelings of pride in their organization and the degree of loyalty towards the achievement of organizational goals. A feeling of commitment means that 
employees participate in the organization and its goals.

Based on the explanation above, it can be concluded that organizational climate is the perception of organizational members regarding the quality of the organization's internal environment that is relatively felt by members of the organization which will then affect their subsequent behaviour. The dimensions used to measure organizational climate are structure, standard, responsibility, recognition, support, and commitment.

A research, conducted by Yulinda Agnes Devianti in 2013: "The Effect of Work Motivation and Organizational Climate on Counsellor Performance in Semarang City Junior High Schools in 2013," is motivated by the problem of the existence of some school counsellors that are unable to do their duties and responsibilities properly and reduce their performance in school. The purpose of this study is to find out the effect of work motivation and organizational climate on the performance of the counsellors in Semarang City Junior High Schools partially and simultaneously.

The research is a correlational quantitative study. The population was 156 counsellors, and samples are taken by random sampling, and 47 counsellors are obtained. Data collection method employs questionnaires and data analysis methods with descriptive analysis and multiple linear regression analysis.

The results reveal the performance of counsellors in Semarang City Junior High Schools in work included in the high performance category. There are $65.96 \%$ of respondents are in the high category; $31.91 \%$ of them are in the very high category; and those included in the category are only $2.13 \%$. This is influenced by motivation and organizational climate on counsellor performance in Semarang City Junior High School, the influence contributed from the two motivation variables and organizational climate on counsellor performance is $76.40 \%$, while the rest is influenced by other factors outside this study.

\subsection{Motivation Theory}

Motivation is an effort made by someone in order to complete the work with enthusiasm because he wants to carry it out (Terry, 2009:130). Furthermore (Buno, 2016:39), explains that motivation can be used to explain why people behave in certain ways to achieve a set of goals. Maslow in Buno (2016:40) suggests five levels of need: self-actualization, appreciation, love, security, and physiological needs. This motivator comes from factors that seem to encourage enthusiasm to achieve higher performance and better quality work. Expectations of progress, for example, cause one to work harder even though at the same time such a lack of hope is not enough to cause that person to leave his job.

Based on this explanation, what is used as an indicator of work motivation are:

a) Physical needs - the most basic needs of humans. Among others; fulfillment of oxygen and gas, liquid (drinks), nutrition (food), elimination, rest and sleep needs, activities, body temperature balance, and sexual.

b) Need for security-the need for security is divided into two namely physical protection and psychological protection. Physical protection, including protection from threats to the body and life such as accidents, diseases, environmental hazards, etc. Psychological protection, protection from the threat of new or unfamiliar events or experiences that can affect one's mental condition.

c) Love needs - the need to have and be owned, give and receive love, warmth, friendship, and family.

d) Award needs - the need for selfesteem and feelings of respect by 
others and recognition from others.

e) Self-actualization needs - the highest requirement in the Maslow hierarchy, in the form of the need to contribute to other people or the environment and achieve their full potential (Maslow in Buno, 2016:40).

A research, conducted by Farida Hanun in 2013 tittled The Influence of SelfEfficacy, Organizational Climate and Achievement Motivation on the Performance of Madrasah Chief (Survey in Ibtidaiyah Madrasah, Bekasi City), is motivated by the problem of the needs for empowerment of performance to Ibtidaiyah schools in order to improve the efficiency of its management. The purpose of this study is to analyse the effect of self-efficacy on the principal's performance, to analyse the influence of the organizational climate felt by the principal on his or her performance and the achievement motivation that the headmaster had on his or her performance.

The number of respondents in this study is 45 respondents from the headmaster of madrasah using the random sampling technique. The analysis technique in this study uses multi-variate analysis.

The results reveal that a) selfefficacy had a direct effect on organizational climate; b) self-efficacy had a direct effect on achievement motivation; c) organizational climate had a direct effect on achievement motivation; d) self-efficacy had a direct effect on the performance of madrasah principals; e) organizational climate had a direct effect on madrasah head performance; and f) achievement motivation directly influences the performance of madrasah principals.

Another research, conducted by I Kadek Vemil (2014) on the effects of leadership and motivation on the performance of the members of the Bogor City Traffic Department, is motivated by work dissatisfaction which ultimately impacts on the members' performance. In order to overcome this, according to Robbin, leadership has a central role in achieving organizational goals and objectives. In addition, according to Terry and Rue, motivation is also able to control one's performance. Based on these results obtained, it is known that there is an influence of leadership on the members' performance by $54.2 \%$, motivation affects the performance of members by $59.1 \%$, while simultaneously performance is influenced by leadership and motivation by $55.7 \%$. Based on the explanation above, it can be concluded that work motivation is a basic impulse that moves people to work, which is dimensioned based on physical, security, love, appreciation and self-actualization needs.

\section{RESEARCH METHODS}

\subsection{Research Approaches and Methods}

This research is an explanatory research. Explanatory research is an explanation and aims to test a theory or hypothesis in order to strengthen or even reject the theory or hypothesis of the existing research results. Research conducted by this researcher is a causal research that examines the causal relationship between two or more variables. In this causal study the researcher wanted to explain the influence of organizational climate and motivation on the performance of Madiun Samsat members.

The research approach used by researchers is a quantitative approach. The quantitative approach focuses the problem on variables (concepts that have a variety of values) and the relationship between these variables by using existing theories. The quantitative approach measures variables in the form of numbers. As for the method used in this research is descriptive analysis. The use of these methods aims to describe the problem under study and also analyse the problems that exist in this study.

\subsection{Variable operationalization}


There are three operational definitions in this study, namely organizational climate as the independent variable 1 (OCV), motivation as the independent variable 2 (MOT) and the performance of Madiun Samsat members as the dependent variable (Y). The independent variable is a variable that influences or influences other variables, while the dependent variable is a variable that is influenced by the independent variables.

Variation operationalization is the translation of a variable concept into a measurement instrument. Based on this explanation, the operationalization of variables in this study is as follows:

a. Organizational climate is the perception of organizational members regarding the quality of the organization's internal environment that is relatively felt by members of the organization which will then affect their subsequent behaviour. Dimensions used to measure organizational climate are structure, standard, responsibility, recognition, support, and commitment. This dimension is then developed into twelve statements and answer choices using a Likert scale with a range of 1 to 5.

b. Work motivation is a basic impulse that moves people to work, which is dimensioned based on physical needs, security needs, compassion needs, appreciation needs and selfactualization needs. This dimension is then developed into fifteen statements and answer choices using a Likert scale with a range of 1 to 5 .

c. Member performance is the result of work both in quality and quantity achieved by a member in carrying out tasks in accordance with the responsibilities given to him. The indicators used to measure the value of the performance variables of Madiun Samsat members. These indicators are quality, quantity, timeliness, effectiveness, and independence. This dimension is then developed into fifteen statements and answer choices using a Likert scale with a range of 1 to 5.

\subsection{Population and Sample}

The population is the overall characteristics of the unit of measurement that is the object of a research (Arikunto, 2006:3). In this study, the population is 57 members of Madiun Samsat. According to Sugiyono (2017: 81), sample is a part of a population, while sample is a part of the population, where the sample consists of a number of members chosen from the population. The research sample is a part of the population that has certain characteristics or circumstances to be measured (Arikunto, 2006: 4).

The sampling technique used in this study is a sampling study technique, which is a sampling method that is done by using all existing populations into a research sample. From the results of the sampling technique, it is obtained samples taken by 57 respondents.

\subsection{Data Collection Techniques}

Data collection techniques used in this study are as follows:

1. Questionnaire - instruments for collecting data or information that are operationalized in the form of items.

2. Library Resources - obtained by finding references from books, articles or from various media that contain complete explanations with theories that have to do with the research problem being studied.

\subsection{Data Analysis Techniques}

Data analysis technique in this research is quantitative analysis technique which is explained through testing the hypotheses of the research respondents' answers. Quantitative analysis is a method of analysing data using calculations. In this 
quantitative analysis the determination of scores is used by changing qualitative data (in the form of giving questionnaires to respondents) into quantitative form. The analytical tools used in this study are as follows:

\section{RESULT}

\subsection{Analysis Results \\ Description of \\ Respondents' Answers to \\ Organizational Climate Variables}

The results of the analysis of the description of respondents' answers to the Organizational Climate variable can be defined as follows:

Table 2: Description of Answers to Organizational Climate

\section{Variables}

\begin{tabular}{|c|c|c|c|c|r|c|c|c|}
\hline No item & F.1 & F.2 & F.3 & F.4 & F.5 & Sigma F & Average F & Category \\
\hline 1. & 12,0 & 6,0 & 26,0 & 4,0 & 9,0 & 163,0 & 32,60 & Middle \\
\hline 2. & 12,0 & 4,0 & 23,0 & 4,0 & 14,0 & 175,0 & 350 & Middle \\
\hline 3. & 9,0 & 8,0 & 4,0 & 21,0 & 15,0 & 196,0 & 39,20 & Middle \\
\hline 4. & 10,0 & 5,0 & 16,0 & 10,0 & 16,0 & 188,0 & 37,60 & Middle \\
\hline 5. & 6,0 & 6,0 & 13,0 & 10,0 & 22,0 & 207,0 & 41,40 & Middle \\
\hline 6. & 6,0 & 6,0 & 13,0 & 10,0 & 22,0 & 207,0 & 41,40 & Middle \\
\hline 7. & 5,0 & 4,0 & 9,0 & 17,0 & 22,0 & 218,0 & 43,60 & High \\
\hline 8. & 3,0 & 2,0 & 17,0 & 17,0 & 18,0 & 216,0 & 43,20 & High \\
\hline 9. & 5,0 & 8,0 & 6,0 & 11,0 & 27,0 & 218,0 & 43,60 & High \\
\hline 10. & 5,0 & 3,0 & 4,0 & 6,0 & 39,0 & 242,0 & 48,40 & High \\
\hline 11. & 3,0 & 5,0 & 8,0 & 8,0 & 33,0 & 234,0 & 46,80 & High \\
\hline 12. & 2,0 & 2,0 & 14,0 & 13,0 & 26,0 & 230,0 & 460 & High \\
\hline \multicolumn{7}{|c}{} \\
\cline { 3 - 6 }
\end{tabular}

\section{Source: Processed Data Results Research Respondents, 2017}

From the results of the above analysis, it can be seen that Organizational Climate variable perceived by respondents is in the average category in the medium category. This is indicated by obtaining an index number of 41.5667 which is in the range of 26.7-41.8, (Respondents' perceptions are based on a range of 26.7-41.8, categorized as being, which indicates the condition of the current Organizational
Climate variable).

\subsection{Normality Test}

Normality test aims to test whether in the regression model, the dependent variable and the independent variables both have normal distributions or not. A good regression model is having a normal or a near normal data distribution (Ghozali, 2006).

Table 3: Normality Test (Kolmogorov-Smirnov)

\begin{tabular}{|c|c|c|c|c|}
\hline & & $\mathrm{OCV}$ & MOT & $\mathrm{Y}$ \\
\hline $\bar{N}$ & & 57 & 57 & 57 \\
\hline \multirow{3}{*}{ Normal Parameters a,b } & Mean & 43,3158 & 43,4737 & 47,8947 \\
\hline & Std. Deviation & 7,90379 & 7,98012 & 7,93429 \\
\hline & Absolute & 0,128 & 0,120 & 0,119 \\
\hline \multirow[t]{2}{*}{ Most Extreme Differences } & Positive & 0,065 & 0,066 & 0,073 \\
\hline & Negative & $-0,128$ & $-0,120$ & $-0,119$ \\
\hline \multicolumn{2}{|c|}{ Kolmogorov-Smirnov Z } & 0,968 & 0,904 & 0,901 \\
\hline \multicolumn{2}{|c|}{ Asymp. Sig. (2-tailed) } & 0,306 & 0,388 & 0,391 \\
\hline
\end{tabular}


a. Test distribution is Normal

b. Calculated from data

Source : Output SPSS19

The test results above reveal an information that the results of the Kolmogorov-Smirnov

(K-S) non- parametric statistical test above are known that the Kolmogorov-Smirnov value is on the Organizational Climate variable is 0.968 and significant at 0.306 . Because the Kolmogorov-Smirnov variable Organizational Climate significance value $>$ significance value (Asymp.sig 0.05), the residuals are normally distributed and the results are consistent with previous tests. From the Kolmogorov-Smirnov test results the interpersonal relationship variable is 0.904 and significant at 0.388 . Because the significance value of Kolmogorov- Smirnov variabel Motivation > significance value (Asymp.sig 0.05), the residuals are normally distributed and the results are consistent with previous tests. While the results of the Kolmogorov-Smirnov test are on the Member Performance variable is 0.901 and significant at 0.391 . Because the Kolmogorov-Smirnov variabel Member Performance value $>$ significance value (Asymp.sig 0.05), the residuals are normally distributed and the results are consistent with previous tests. From the results of these tests, it can be ascertained that all variables are normally distributed.

\subsection{Results of Multiple Linear Regression Test Organizational Climate Variables (OCV) and Work Motivation (MOT) Against Police Member's Performance (Y).}

The multiple linear regression equation is used to determine the influence of the independent variables, among others: Organizational Climate (OCV), Motivation (MOT), to the dependent variable namely Member Performance (Y) with output that can be seen in the following table:

Table 4. Output Multiple Regression Linier

\begin{tabular}{|c|c|c|c|c|c|}
\hline \multirow[t]{2}{*}{ Model } & \multicolumn{2}{|c|}{$\begin{array}{c}\text { Unstandardized } \\
\text { Coefficients }\end{array}$} & $\begin{array}{c}\text { Standardized } \\
\text { Coefficients }\end{array}$ & \multirow[t]{2}{*}{$\mathrm{T}$} & \multirow[t]{2}{*}{ Sig. } \\
\hline & B & Std. Error & Beta & & \\
\hline \multirow{3}{*}{$\begin{array}{c}\text { (Constant) } \\
1 \mathrm{OCV} \\
\text { MOT }\end{array}$} & 6,1940 & 2,3710 & & 2,6120 & 0,0120 \\
\hline & 0,3910 & 0,0960 & 0,3900 & 4,0710 & 0,0000 \\
\hline & 0,5690 & 0,0950 & 0,5720 & 5,9760 & 0,0000 \\
\hline
\end{tabular}

a. Dependent Variable: Police Member's Performance

Source : Output SPSS19

Based on the table on the results of testing with SPSS, we get multiple linear line equations (as seen from the nonstandardized coefficients) obtained:

$\hat{\mathrm{Y}}=6.194+0.391 \mathrm{OCV}+0.569 \mathrm{MOT}$

Based on the equation can be seen that:

a. Constant regression coefficient known to be 6.194 is positive, tends to if there are changes in the independent variables of Organizational Climate (OCV), Motivation (MOT), then the value of the dependent variable of Member Performance (Y) is 6.194. The regression coefficient of the variable Organizational Climate (OCV) is known to be 0.391 is positive it tends to be that the stronger the influence of the Organizational Climate (OCV), the higher the Member Performance (Y) will tend to be. Conversely, the weaker the influence of the Organizational Climate (OCV), the lower the Member Performance (Y) tends to be.

b. Motivation variable regression coefficient (MOT) is known 0.569 is 
positive it tends to be that the stronger the influence of Motivation (MOT), the the Member Performance (Y) will tend to be. Conversely, the weaker the influence of Motivation (MOT), the lower the Member Performance (Y) tends to be.

\subsection{Hypothesis Test result}

a). Test Results F

The $F_{\text {test }}$ is used to test whether there is higher

an influence between Organizational Climate variables (OCV), Motivation (MOT), simultaneously on the dependent variable namely Member Performance (PMP), with the significance level used to be $5 \%$ (Ghozali, 2006). Based on the results of the $F_{\text {test }}$ analysis the effect is known as follows.

Table 5: Test Output F

\begin{tabular}{|c|c|c|c|c|c|}
\hline \multicolumn{5}{|c|}{ ANOVAa } \\
\hline Model & Sum of Squares & df & Mean Square & F & Sig. \\
\hline Regression & 3016,4990 & 2,0 & 1508,2490 & 160,0520 & $0,0000 \mathrm{~b}$ \\
Residual & 508,8700 & 54,0 & 9,4240 & & \\
Total & 3525,3680 & 56,0 & & & \\
\hline
\end{tabular}

Source: Output SPSS19

Based on the table above, the results of testing with SPSS obtained the calculated $\mathrm{F}$ number between the independent variables of Organizational Climate (OCV), Motivation (MOT), simultaneously to the dependent variable namely Member Performance (Y), has a calculated $F$ value of 160.052 and a significance value of 0.000 smaller than the significance level of $5 \%$ or 0.05 , it means that it is located in the area ha1 accepted. This means that the Organizational Climate variable (OCV), Motivation (MOT), simultaneously influences and is significant to the dependent variable (PMP), namely b. Predictors: (Constant), MOT, OCV Members' Performance (Y). So, from the results of the $\mathrm{F}$ test it is known that the regression model in this study is said to be fit or feasible.

\subsection{Determination Coefficient Test Results}

Determination coefficient test is used to measure how far the ability of the model on the independent variable Organizational Climate (OCV), Motivation (MOT), in explaining the variation in dependent variables Performance of Madiun Samsat Members (Y), with the following output:

Table 6 Output Coefficient of Determination

\begin{tabular}{|c|c|c|c|c|}
\hline Model & $\mathrm{R}$ & $\mathrm{R}$ Square & $\begin{array}{c}\text { Adjusted R } \\
\text { Square }\end{array}$ & Std. Error of the Estimate \\
\hline 1 & $0,9250 \mathrm{a}$ & 0,8560 & 0,8500 & 3,069770 \\
\hline
\end{tabular}

a. Predictors: (Constant), OCV, MO

Source : Output SPSS19

Based on the results of the regression test in the table above, it is obtained the coefficient of determination $\left(\mathrm{R}_{\text {Square }}\right)$ of 0.856 . This means that the Organizational Climate 
variable (OCV), Motivation (MOT) has a contribution of $85.6 \%$ in explaining Member Performance (Y). While other factors such as discipline, member competency and job satisfaction of members that influence the Performance of Members (Y) but not examined in this study, which has a contribution of $(100 \%-85.6 \%)=14.4 \%$.

\section{DISCUSSION}

\subsection{Analysis of the Effect of Organizational Climate on the Performance of Madiun Samsat Members}

Based on the results of testing the first hypothesis it is known that there is acceptance of the second hypothesis which states that there is an influence of organizational climate on the performance of Madiun Samsat members. The acceptance of this hypothesis can be seen in the t-count between the climate of the organization against the performance of Madiun Samsat members who have a t-count of 4.071 and a significance value of 0,000 smaller than the significance level of $5 \%$ or 0.05 ; means that it is located in the ha 2 area accepted, so that partially there is a significant influence between Organizational Climate (OCV) on Member Performance (Y).

The amount of the acceptance there is a significant influence

between organizational

climate on the performance of members of

Madiun Samsat then it can be observed that the regression coefficient of organizational climate (OCV) is known

0.391 is positive tends to be that the stronger the influence of the Organizational Climate (OCV), the higher the Member Performance (Y1). Conversely, the Dependent Variable: PMP the weaker the influence of the Organizational Climate (OCV), the lower the Member Performance (Y) tends to be.

These findings are also consistent with the findings of Farida's (2013) research and the results of a study conducted by Yulinda (2013) who both mentioned that there was a partially good effect between organizational climate on performance. Where based on the findings of this study it can be explained that in order to improve the performance of Madiun Samsat members an improvement in the Organizational Climate can be used by the members. Where this Organizational Climate can then provide the attribution function of the organization or as an attribution of the individual's own perception. So with a good perception from a member of his work, he will be motivated to work as well as possible. Such explanation is also in accordance with the opinion of Simamora (2004:81) who explains that the organizational climate in the form of an internal environment or organizational psychology can affect a person's condition in carrying out their activities, so that the performance produced by members is good, it can be created from internal environmental conditions and good condition of organizational psychology.

The acceptance of this hypothesis is also in accordance with the explanation put forward by Lussier (2005: 486), stating that organizational climate can influence their behaviour at work so that from this explanation it can be stated that Organizational Climate perceived by someone influences the results of one's performance. This explanation is also in accordance with the opinion of Wirawan (2007:121), stating that the organizational climate is a quality of the internal environment that is relatively ongoing, experienced by members of the organization, influencing the behaviour of each member, where this is furthermorcan have an impact on the work he does.

The results of this study can be shown from the results of the analysis of the frequency of respondents' answers from Organizational Climate variables perceived by the average respondent to be in the moderate category, which is indicated by obtaining an index number of 41.5667 which is in the range of 26.7-41.8, and the results analysis of the frequenc of respondents'answers of the member performance variable perceived by 
espondents to be in the medium category. This is indicated by obtaining an index number of 36.4 , which is also in the same range. Where with these results can prove that if the organizational limate is moderate, then the performance of the members produced will also be.

The dominant organizational climate influences the performance of Madiun Samsat members from the support indicator with a total number of respondents 83 people or $145.6 \%$, with the respondents' answers answering Strongly Agree and Agree on these indicators when compared with other indicators. The amount of respondents who are Strongly Agree and Agree who always support members so that the organizational climate felt by these respondents is able to give effect to each member to work well in the workplace. Meanwhile, when viewed from the results of the analysis per indicator of organizational climate variables that show that the strongest indicator comes from the responsibility indicator which shows the regression coefficient value of the responsibility indicator of 0.977 , which means the stronger the influence of the Work Climate variable responsibility indicator (OCV) then will tend to be higher Member Performance (Y). Conversely, the weaker the influence of the Work Climate variable responsibility indicator $(\mathrm{OCV})$, the lower the Member Performance (Y) tends to be.

Acceptance of the hypothesis that there is an influence of Organizational Climate on this performance can also be explained from the existence of positive working environment conditions which will then form a good Organizational Climate condition that can be felt by members when working, so this impacts on the feeling of comfort in carrying out their duties, so he will be able to work well.

Acceptance of this hypothesis can also be explained further from the condition of someone who when working always has a positive outlook on the work environment that will make a person become enthusiastic at work, so that the impact is to produce the best performance of members who have such high motivation and feel comfortable with the Organizational Climate. . In addition, the acceptance of this hypothesis can also be explained by the existence of hard work and in accordance with responsibilities, as well

sensitive to someone's work environment that will be able to make someone able to survive and continue to strive in completing his work, so that members can produce the best performance. Acceptance of this hypothesis can also be explained by the existence of decision-making conditions that are in accordance with existing policies and regulations, an attitude of respecting one's characteristics, a desire to mutually maintain work balance between rights and obligations as well as providing motivation to other members and also able to make someone to work better again and produce the best performance.

The acceptance of this hypothesis can also be explained by the existence of high conditions of trust in members of the team, the desire to maintain good relations between fellow members, with leaders and subordinates, as well as feeling proud of all elements incorporated in the organization can also make someone work well, so the 
resulting performance is also good. In addition there is the attitude of one's work loyalty at work, the freedom of members when working independently and the demands of each member to be able to complete their duties and obligations to the organization will also be able to bring someone in one's condition to carry out their work better and provide the best results.

Based on some of these explanations, it can be seen that the reasons for accepting hypotheses are the influence of organizational climate on member performance. Based on these findings, it can then be said that the organizational climate influences member performance.

\section{Analysis of the Effect of Motivation on the Performance of Members of Madiun Samsat}

The influence of motivation on the performance of Madiun Samsat members can be explained from the results of the third hypothesis testing. The acceptance of this hypothesis can be seen in the t-arithmetic between motivation to the performance of Samsat Madiun members who have a tarithmetic of 5.976 and a significance value of 0.013 smaller than the significance level of 0.05 ; means that it is located in the area ha3 accepted, so that partially there is a significantly influence between Motivation (MOT) on Member Performance (Y).

The amount of the acceptance there is a significant influence between organizational climate on the performance of members of Madiun Samsat, then it can be observed that the regression coefficient of variable Motivation (MOT) is known to be 0.569 is positive, it tends to be that the stronger the influence of Motivation (MOT), the higher the Member Performance (Y2). Conversely, the weaker the influence of Motivation (MOT), the lower the Member Performance (Y) tends to be.

The results of this study are consistent with the findings of research conducted by Kadek Vemil (2014) and the results of research conducted by I Dewa Gde Ditya
Krishnandha (2013) and the results of research conducted by Farida (2013) and the results of research conducted by Yulinda (2013) the same mentioned there is a partial good effect between work motivation on performance.

The findings of the analysis can also be explained from the results of the descriptive analysis of respondents' answers between motivation and performance that are in the same category. Where this is known based on respondents' answers from work motivation variables perceived by respondents to be in the medium category based on index numbers of 33.93 which are in the range of 26.7-41.8. And this is in accordance with the answers of respondents on the variable performance of members who perceived respondents on average are in the medium category, which is also equally in the range.

While the strongest dominant indicator in providing influence on member performance is derived from the indicator of safety needs of variable Work Motivation (OCV) it is known that 0.996 is positive, it tends to be the stronger the influence of the indicator of safety needs variable Work Motivation (OCV) will tend to be higher Member (Y). Conversely, the weaker the influence of the indicator of the need for safety variables Work Motivation (OCV), the more likely the lower the Performance of Members (Y).

While based on the analysis of the answers of respondents who gave answers strongly agree and agree on the variable work motivation, which has the most answers coming from indicators of self- actualization needs with a total number of respondents 90 people or $157.89 \%$, when compared with other indicators. The amount of respondents who are Strongly Agree and Agree who always support members so that the work motivation of the respondents is able to give effect to each member to work well in the workplace, because this can be caused by the development of science and technology today. Because all types of human activity 
can now be facilitated by technology, the biggest demand they feel is their actualization. From the demands in all activities, so that their activities are easier to do, this further makes them feel their greatest need now is the need for selfactualization. This is in line with the use of self-actualization needs which is then functioned to perform the performance of the members while in the ministry. Where based on the subsequent findings on the performance variable members who have the most answers come from indicators of independence with a total number of respondents 79 people or $138.6 \%$, with respondents' answers answering Strongly Agree and Agree on these indicators when compared with other indicators. The number of respondents who Agree Strongly Agree and Agree who always support members so that the performance produced by respondents is due to the performance conditions must be done by each member independently, this is strongly supported by the fulfillment of self-actualization needs. So, from the findings, this can be used to explain the influence of motivation that comes from the need for self-actualization of the members' performance when working independently.

The results of this study are consistent with the opinion expressed by Terry (2009:130), stating that motivation or effort made by someone can be beneficial for someone to complete the work. The findings of this study are also in accordance with the opinion of Uno (2016:39), who explains that motivation can be used to explain why people behave in certain ways to achieve a set of goals. The explanation of the acceptance of this hypothesis is also in accordance with Maslow's opinion in Uno (2016:40), who proposes five levels of needs: selfactualization, appreciation, love, security, and physiological needs, which can further encourage a person to be more enthusiastic in achieving performance and carry out higher quality work.

This acceptance can also be explained further from the condition of someone who is satisfied with his income at work and can also make someone work harder so that the results of better performance. The acceptance of this hypothesis can also be shown by the members of Madiun Samsat who are satisfied with the benefits provided, enjoy the work facilities provided by the organization, so that this can encourage a person to be more enthusiastic in working, and the impact is that the performance will be better.

There is a motivational influence on the performance produced by a member can also be explained from the existence of members who in carrying out their work feel protected from feelings of fear, stress, and anxiety, as well as the fulfillment of security needs when carrying out their work this can make someone work well and finally produce good performance too. In addition there is environmental support around a good place and makes it comfortable for someone when working.

The acceptance of the members by other units or fellow members of Madiun Samsat, leaders and the community is also able to make a person more enthusiastic in working because he feels respect for him so that members who feel that way will produce the best performance. The influence of motivation on the performance produced by a member can also be explained from the condition of members who have a good relationship, and loving one another's friends will foster enthusiasm in working and the impact is that the resulting performance will be better. In addition, the presence of coworkers who have a sympathetic and friendly attitude are also able to make someone motivated to work better so that this will have an impact on the resulting performance results.

The influence of motivation on the performance produced by a member can also be explained from the appreciation for work performance from the head of the Madiun Police Resort. 


\section{Analysis of Simultaneous Effects of Organizational Climate and Motivation on the Performance of Madiun Samsat Members}

Based on the results of the hypothesis test conducted by the F-test, it is known that there is an acceptance of the hypothesis which states that the organizational climate and motivation have significantly influence the performance of Madiun Samsat members. The acceptance of this hypothesis is shown in the calculated F- value between the organizational climate and motivation towards the dependent variable, namely the performance variable of Madiun Samsat members by 160,052 and the significance value of 0,000 is smaller than the significance level of $5 \%$ or 0.05 , meaning that it is located in the accepted area. Organizational Climate (OCV), Motivation (MOT), together (simultaneously) have influential and significant effect on the dependent variable namely Member Performance (Y). So from the results of the F-test it is known that the regression model in this study is said to be feasible.

In order to measure the influence of these two variables, it can be observed in the determination coefficient test used to measure how far the ability of the model on the independent variable Organizational climate (OCV), Motivation (MOT), in explaining the variation of dependent variables Performance of the members Madiun Samsat (Y), which from the results of this determination coefficient test obtained by the coefficient of determination (RSquare) of 0.856 . This means that the Organizational Climate variable (OCV), Motivation (MOT) has a contribution of $85.6 \%$ in explaining the Member Performance (Y). While other factors that affect Member Performance (Y) not included in this study contributed $(100 \%$ $85.6 \%)=14.4 \%$. Whereas if you want to know which is greater between the two variables can be seen in this regression equation $\hat{Y}=6.194+0.3910 C V+0.569 \mathrm{MOT}$.
Based on these equations, it can be seen that the value of the constant regression coefficient known to be 6.194 is positive, and if there is a change in the independent variables of Organizational Climate (OCV), Motivation (MOT), the value of the dependent variable of Member Performance (Y) is 6.194. While the value of the influence on the variable Organizational Climate variable (OCV) is known to be 0.391 is positive it tends to be that the stronger the influence of the Organizational Climate (OCV), the higher the Member Performance (Y) will tend to be. Conversely, the weaker the influence of the Organizational Climate (OCV), the lower the Member Performance (Y) tends to be. From the equation it is also known the effect value of the Motivation variable (MOT) is known to be 0.569 is positive it tends to be that the stronger the influence of Motivation (MOT) the higher the Member Performance (Y) will tend to be. Conversely, the weaker the influence of Motivation (MOT), the lower the Member Performance (Y) tends to be.

The acceptance of this hypothesis can also be explained by the existence of hard work and in accordance with responsibilities, as well as being sensitive to someone's work environment that will be able to make someone able to survive and continue to strive to complete their work, so that members can produce the best performance. The execution of duties, according to responsibilities, decision making in accordance with existing policies and regulations, an attitude of respect for someone's characteristics, a desire to maintain work balance between rights and obligations and provide motivation to other members also can make someone work better and produce the best performance. 
The acceptance of this hypothesis can also be explained by the existence of high conditions of trust in members of the team, the desire to maintain good relations between fellow members, with leaders and subordinates, as well as feeling proud of all elements incorporated in the organization can also make someone work well, so the resulting performance is also good.

The Acceptance of this hypothesis can also be explained by the attitude of one's work loyalty in work, the freedom of members when working independently and the demands of each member to be able to complete their duties and obligations to the organization will also be able to bring someone in one's condition to carry out their work better and provide the best results.

The acceptance of this hypothesis can also be explained from the condition of someone who is satisfied with his income at work can also make someone work harder so that the results of better performance. Acceptance of this hypothesis can also be shown by members of the Satpas Madiun District Police who are satisfied with the benefits provided, enjoy the work facilities provided by the organization, so that this can encourage a person to be more enthusiastic in working, and the impact is that the performance will be better.

The acceptance of this hypothesis can also be explained by the presence of members who in carrying out their work feel protected from feeling afraid, depressed, and anxious, as well as fulfilling their security needs when carrying out their work this can make a person work well and ultimately produce good performance as well.

A good performance can also result from having environmental support around a good place and making it comfortable for someone to work. The acceptance of the members by other units or fellow of Madiun Police Resort members, leaders and the community is also able to make someone more enthusiastic in working because he feels respect to him so that members who feel that way will produce the best performance.

The acceptance of this hypothesis can also be explained from the condition of members who have a good relationship, and loving one another's friends will foster enthusiasm at work and the impact is that the resulting performance will be better. In addition, the presence of co-workers who have a sympathetic and friendly attitude are also able to make someone motivated to work better so that this will have an impact on the resulting performance results.

The appreciation of work performance from the head of the Madiun Police Resort can encourage someone to be more active in carrying out their duties, so that someone will be better at work and the impact will be better performance.

\section{CONCLUSION}

Based on the results of the discussion above, it can be concluded that:

1) Organizational climate and work motivation simultaneously influence the performance of Madiun Samsat members, with the more dominant influence coming from work motivation

2) The organizational climate partially influences the performance of Madiun Samsat members, with the most dominant indicator at work is the indicator of responsibility.

3) Work motivation partially influences the performance of Madiun Samsat members, with the dominant influence coming from indicators of self-actualization needs.

\section{IMPLICATION}

1) In order to improve the performance of Madiun Samsat members, the chief of Madiun Police Resort should adopt a policy to motivate members more so that members are more enthusiastic in working, and always maintain an organizational climate that is always conducive when working so that members who work do not experience 
interference from internal parties.

2) In order to improve the performance of members, all leaders should evaluate the performance of members, starting from personal needs related to the use of information technology, so that by meeting these needs, members can work independently and be able to complete their tasks as effectively as possible.

3) In order to improve the performance of members, all leaders should create a conducive organizational climate by paying attention to the responsiveness of each member and always providing support to his or her members to always work as well as possible.

4) Related to further research in order to improve the performance of members, it is expected that further research can examine the organizational climate variables, motivation, and other variables such as the level of discipline, member competence and member job satisfaction, with a greater number of respondents.

\section{REFERENCES:}

Books:

Arikunto, Suharsimi. 2006. Prosedur Penelitian Suatu Pendekatan Praktik. Jakarta: Rineka Cipta.

B. Uno, Hamzah. 2008. Teori Motivasi dan Pengukurannya. Jakarta : Bumi Aksara.

Bernard JM \& Goodyear RK.2004. Fundamentals of Clinical Supervision. Boston, MA: Pearson Education.

Chariri dan Imam Ghozali. 2000. Teori Akuntansi. Semarang: UNDIP.

Dale, Timpe. 2004. Seri Manajemen Sumber Daya Manusia Kinerja, cetakan kelima. Jakarta: PT Elex Media Komputindo.

Dimyati dan Mudjiono. 2009. Belajar dan Pembelajaran. Jakarta: PT Rineka Cipta.

Ghozali, Imam, 2009. Aplikasi Analisis Multivariate Dengan Program SPSS, Edisi Ke-empat. Semarang: Penerbit
Universitas Diponegoro.

Hasibuan, Malayu. 2000. Manajemen Sumber Daya Manusia. Jakarta. Bumi aksara.

Henry, Simamora. 2004. Manajemen Sumber Daya Manusia, Edisi 3, Cetakan

1. Yogyakarta: Penerbitan STIE YKPN.

Lussier, N Robert. 2005. Human Relations in OrganizationApplications and skill Building. New York: Mc Graw Hill.

Purwanto. 2011. Evaluasi Hasil Belajar. Yogyakarta: Pustaka Pelajar.

Robbins, Stephen P. \& Coulter, Mary. 2010. Manajemen, Edisi 10, Jilid 1 dan 2. Jakarta: Penerbit Erlangga.

Siagian, Sondang P. 2004. Manajemen Sumber Daya Manusia. Jakarta: Bumi Aksara.

Sugiyono. 2010. Metode Penelitian Kuantitatif Kualitatif \& RND. Bandung: Alfabeta.

Wirawan. 2007. Budaya dan iklim organisasi: Teori, aplikasi, dan penelitian. Jakarta: Salemba Raya.

$\underline{\text { Journals }}$

Afifah, Siti N. 2015 dengan Judul Pengaruh Motivasi Pimpinan Terhadap Kinerja Pegawai Negeri Sipil Di Satuan Lalu Lintas Kepolisian Resort Jember.

Eisenberger, R., Huntington, R., Hutchinson, S., Sowa Debora. 1986. Perceived organizationa support. Journal Of Applied Psychology. Vol 71. Pp. 500-507.

Herman, Djailani dan Sakdiah Ibrahim, 2014 dengan Judul Pengaruh Iklim Organisasi dan Kepuasan Kerja Terhadap Kinerja Guru.

Nicko Achmad Pradityo, Rodhiyahdan Saryadi, 2012 dengan Judul Pengaruh Kepemimpinan dan Iklim Organisasi Terhadap Kinerja Karyawan PT. Telkom Indonesia Semarang.

Siswanto, Eko A.2012. Analisis Pengaruh 
Iklim Kerja dan Pengembangan

Karir Terhadap Komitmen Karir:

Kepuasan Kerja Sebagai Variabel

Intervening (Studi Kasus pada

Karyawan P.T. Pertamina (Persero)

Pemasaran Wilayah Jawa Tengah dan DIY) Diponegoro, Business Review, Volume 1, No.2, 2012, pp.332-342.

Regulations:

Perkap Polri No. 6 Tahun 2011 tentang Sistem Manajemen Kinerja

Perkap No. 18 Tahun 2012 Tentang Indikator Kinerja Utama Polri

Undang-Undang Nomor 2 Tahun 2002 tentang Kepolisian Negara Republik Indonesia. 